\title{
Performance of Different Crop Geometry on Yield Advantage Assessment and Economics of Pigeonpea (Cajanus cajan) + Niger (Guizotia abyssinica Cass.) Intercropping System
}

\author{
Y. Lavanya ${ }^{1 *}$, N.G. Kurhade ${ }^{2}$ and G.R. Pawar ${ }^{2}$ \\ ${ }^{1}$ T.N.A.U. Coimbatore, Tamil Nadu, India \\ ${ }^{2}$ V.N.M.K.V. Parbhani, Maharashtra, India \\ *Corresponding author
}

\begin{tabular}{|c|}
\hline Keywords \\
\hline $\begin{array}{l}\text { Economics, } \\
\text { Intercropping, Niger, } \\
\text { Plant geometry, } \\
\text { Pigeonpea, Yield }\end{array}$ \\
\hline Article Info \\
\hline $\begin{array}{l}\text { Accepted: } \\
18 \text { October } 2018 \\
\text { Available Online: } \\
10 \text { November } 2018\end{array}$ \\
\hline
\end{tabular}

A B S T R A C T
The field experiment was conducted during Kharif 2017 at the Experimental Farm, Agronomy Section, College of Agriculture, Parbhani (Maharashtra). The experiment was laid out in randomized block design with three replications. There were total 8 treatments combination consisting 3 row spacing of pigeonpea combined with 2 intra-row spacings and 2 sole cropping treatments of pigeonpea and niger in the recommended spacing of respective crops added. The intercropping system of pigeonpea + niger crops was tried with row proportion of $1: 2,1: 2,1: 3,1: 3,1: 4$ and $1: 4$ in $90 \mathrm{x} 30 \mathrm{~cm}, 90 \mathrm{x} 45 \mathrm{~cm}, 120 \mathrm{x}$ $30 \mathrm{~cm}, 120 \times 45 \mathrm{~cm}, 150 \times 30 \mathrm{~cm}$ and $150 \times 45 \mathrm{~cm}$ planting geometry of pigeonpea in treatments $\mathrm{T}_{1}, \mathrm{~T}_{2}, \mathrm{~T}_{3}, \mathrm{~T}_{4}, \mathrm{~T}_{5}$ and $\mathrm{T}_{6}$ respectively. Studied planting geometry of sole treatments $T_{7}$ and $T_{8}$ of pigeonpea and niger were $90 \times 20 \mathrm{~cm}$ and $30 \times 10 \mathrm{~cm}$ respectively. Inter row and intra row spacing of niger in intercropping treatments were same i.e. $30 \mathrm{x}$ $10 \mathrm{~cm}$. Among all the treatments of pigeonpea + niger intercropping system under rainfed condition, $\mathrm{T}_{7}$ i.e. sole pigeonpea with planting geometry $(90 \times 20 \mathrm{~cm})$ recorded higher pigeonpea equivalent yield $(1650 \mathrm{~kg}$ ha) and $\mathrm{B}$ : $\mathrm{C}$ ratio (3.74) which was followed by treatment $\mathrm{T}_{3}, \mathrm{~T}_{5}$ and $\mathrm{T}_{1}$ i.e. row ratio 1: $3(120 \mathrm{x} 30 \mathrm{~cm}), 1: 4(150 \times 30 \mathrm{~cm})$ and $1: 2(90 \mathrm{x}$ $30 \mathrm{~cm}$ ). Hence intra-row spacing $30 \mathrm{~cm}$ under $90 \mathrm{~cm}, 120 \mathrm{~cm}$ and $150 \mathrm{~cm}$ of pigeonpea row spacing along with 1:2,1:3 and 1: 4 pigeonpea + niger row proportion produced higher pigeonpea equivalent yield than intra row spacing $45 \mathrm{~cm}$ in intercropping system.

\section{Introduction}

Change in climate is likely to aggravate the problems of future food security by exerting pressure on agriculture. India is more vulnerable to climate change in view of the high population depending on agriculture, excessive pressure on natural resources and poor coping mechanisms. In India significant impacts have been implied with medium term (2010-2039), climate change, predicted to reduce yields by $4.5-9 \%$, which is roughly up to $1.5 \%$ of GDP per year (Jasna et al., 2014). Intercropping, an important feature of traditional dryland farming has been successfully exploited to increase productivity per unit of land and water in semiarid tropics. The system of intercropping not only saves the crops against natural hazard but also helps in 
better utilization of farm resources. Intercropping, under rainfed ecosystem, ensures stability in yield and minimizes risk of crop loss due to aberrant weather condition. Therefore under rainfed condition where the chances of crop failure are more, intercropping is more stable and dependable than sole crops (Willey et al., 1980). The main advantage of the intercropping is that the component crops are able to use the growth resources differently and make better overall use of growth resources than grown separately (Willey 1979).

Limited and scanty rainfall in the rainfed areas makes pigeonpea vulnerable to experience moisture stress conditions during the latter part of its growth, resulting in severe yield reduction as it was observed during Kharif 2014. Sufficient soil moisture is the key to successful crop production in dryland areas. The cropping system and planting patterns are effective in increasing the productivity and water use by pigeonpea under rainfed conditions (Ghosh et al., 2005). Pigeonpea based intercropping systems have proved sustainable in respect of yield and income with short duration intercrops of cereals, pulses and oilseed crop across diverse rainfed agro ecologies in India (Rao et al.,., 2003).

In the scarcity zone of Maharashtra, pigeonpea is cultivated during kharif under diverse biophysical (soil and rainfall types) and socioeconomic settings, thus always risk prone due to in-season drought, particularly in shallow to medium black soils, abiotic factors often resulting in unsustainable yields and income. Among the abiotic constraints, the methods of planting and plant population play an important role in production of grain yield of pigeonpea. Thus it becomes necessary to develop an efficient and profitable pigeonpea based intercropping system for scarcity zone of Maharastra.

Pigeonpea is a highly drought resistant crop it can successfully grow in areas receiving only $65 \mathrm{~cm}$ annual rainfall, as the crop matures fast and pest damage is low. It is mostly photoperiodic sensitive and short days result in reduced vegetative phase and onset of flowering. Pigeonpea can be knitted into many cropping systems, viz., intercropping, mixed cropping and sequential cropping etc. The initial slow growth, deep rooting pattern, ability to tolerate drought and low soil moisture has made it highly suitable crop for intercropping systems. It is intercropped with many short duration legumes, cereals and commercial crops.

Niger [Guizotia abyssinica] commonly known as ramtil, kalatil, gurellu, tilangi and noong is a minor oilseed crop of India. The important feature of this crop is that it gives reasonable seed yield even under poor marginal growing conditions like less fertile soil the oil from niger is valued for using different purposes like - culinary, anointing the body, manufacturing of paints and soft soaps, lightening and lubrication and as a base oil by the perfume industries. The oil is good absorbent of fragrance of flowers due to which it is used as base oil by perfume industry. Niger oil is a substitute for sesamum oil for pharmaceutical purposes. An account of these facts in view, an experiment was undertaken to study "Performance of different crop geometry on yield and economics of Pigeonpea (Cajanus cajan) + Niger (Guizotia abyssinica) Intercropping system under rainfed condition".

\section{Materials and Methods}

The experiment was conducted during kharif 2016 on a medium black soil at the research farm of Division of Agronomy, Vasantrao Naik Marathwada Krishi Vidhyapeeth, Parbhani. Geographically location of the site is situated at $19^{0} 16^{\prime}$ North latitude and $76^{\circ} 47^{\prime}$ East longitudes and at 409 altitudes above sea 
similar trend as that of seed yield $\left(\mathrm{kg} \mathrm{ha}^{-1}\right)$ of pigeonpea. The higher Stalk yield $\left(\mathrm{kg} \mathrm{ha}^{-1}\right)$ and biological yield $\left(\mathrm{kg} \mathrm{ha}^{-1}\right)$ of pigeonpea was recorded in dense planting geometry i.e. sole pigeonpea $(90 \times 20 \mathrm{~cm})$ and it was substantially higher than rest of the row spacings and planting geometries. This might be attributed to higher growth rate of pigeonpea under dense planting, whose planting geometry helped for better light interception by crop coupled with high plant population as compared to other row spacings and planting geometries. This indicated that higher plant population with better crop geometry harvested maximum sun light, space and nutrients and resulted into higher growth and more dry matter accumulation with agreement of the research findings of Sonawane et al.,(2011).

Higher niger seed yield $\left(853.9 \mathrm{~kg} \mathrm{ha}^{-1}\right)$, straw yield $\left(4652.66 \mathrm{~kg} \mathrm{ha}^{-1}\right)$ an biological yield $\left(5506.56 \mathrm{~kg} \mathrm{ha}^{-1}\right)$ were recorded in sole planting of niger $(30 \times 10 \mathrm{~cm})$. Similar findings were also reported by Patil and Joshi (2002), Yadav and Maurya (2012) and Sonawane et al.,.(2011).

\section{Assessment of yield advantage in intercropping}

Pigeonpea equivalent yield $\left(\mathrm{kg} \mathrm{ha}^{-1}\right)$ differed markedly among the treatments comprising of planting geometry adapted to pigeonpea and proportions of pigeonpea and niger. Significantly higher pigeonpea equivalent yield $\left(1721.01 \mathrm{~kg} \mathrm{ha}^{-1}\right)$ was obtained in narrow planting geometry of sole pigeonpea $(90 \mathrm{x}$ $20 \mathrm{~cm}$ ). The higher pigeonpea equivalent yield was due to higher seed yield of pigeonpea. The results are in line with the findings of research conducted on competitive performance of pigeonpea based intercropping systems in northern transitional zone of Karnataka by Rathod et al., (2004). The lower pigeonpea equivalent yield $\left(\mathrm{kg} \mathrm{ha}^{-1}\right)$ was recorded in wider planting geometry of pigeonpea + niger $(150 \times 45 \mathrm{~cm})$ row proportion $\left(898.66 \mathrm{~kg} \mathrm{ha}^{-1}\right)$. This could be attributed to lesser aggressivity of pigeonpea in pigeonpea + niger intercropping system.

Land equivalent ratio (LER) differed significantly due to intercropping treatments comprising of planting geometry and row spacings. In general, all the intercropping treatments recorded higher LER values than sole cropping treatments. The significantly higher LER was recorded when niger intercropped with pigeonpea in $120 \times 30 \mathrm{~cm}$ in 1: 3 row proportion followed by planting geometry $150 \times 30 \mathrm{~cm}$ with 1:4 row proportion. Higher LER values in the above mentioned intercropped treatments were due to higher yield of component crops in relation to their sole crops. This was evident by higher combined seed yield per plant of both the crops per unit area. The higher combined seed yield could intern related to the fact that component crops differed in utilization of growth resources and converting them more efficiently into yield components resulting in higher yield per plant and yield per unit area. The study conducted at Kolhapur (M.S.) (Gare et al.,.(2004) revealed higher LER in pigeonpea + soybean intercropping system in wider row spacing than sole crop.

Aggressivity differed significantly due to intercropping treatments comprising of planting geometry and row spacings. In general, all the intercropping treatments recorded positive aggressivity values. The significantly higher aggressivity was recorded when niger intercropped with pigeonpea in $120 \times 30 \mathrm{~cm}$ in $1: 3$ row proportion followed by planting geometry $150 \times 30 \mathrm{~cm}$ with similar row proportion. Higher aggressivity values in the above mentioned intercropped treatments were due to relative yield increase in component a. is greater than that for component b (Table 1-3). 
Table.1 Seed yield $\left(\mathrm{kg} \mathrm{ha}^{-1}\right)$, stalk yield $\left(\mathrm{kg} \mathrm{ha}^{-1}\right)$, biological yield $\left(\mathrm{kg} \mathrm{ha}^{-1}\right)$ and harvest index $(\mathrm{HI})(\%)$ of pigeonpea and niger as influenced by different treatments

\begin{tabular}{|c|c|c|c|c|c|c|c|c|}
\hline \multirow[t]{2}{*}{ Treatments } & \multicolumn{2}{|c|}{$\begin{array}{l}\text { Seed yield } \\
\left(\mathrm{kg} \mathrm{ha}^{-1}\right)\end{array}$} & \multicolumn{2}{|c|}{$\begin{array}{l}\text { Stalk yield } \\
\left(\mathrm{kg} \mathrm{ha}^{-1}\right)\end{array}$} & \multicolumn{2}{|c|}{$\begin{array}{l}\text { Biological yield } \\
\quad\left(\mathrm{kg} \mathrm{ha}^{-1}\right)\end{array}$} & \multicolumn{2}{|c|}{$\begin{array}{c}\text { Harvest index } \\
(\%)\end{array}$} \\
\hline & Pigeonpea & Niger & $\begin{array}{c}\text { Pigeonpe } \\
\text { a }\end{array}$ & Niger & $\begin{array}{c}\text { Pigeonpe } \\
\mathbf{a}\end{array}$ & Niger & $\begin{array}{c}\text { Pigeonpe } \\
\text { a }\end{array}$ & Niger \\
\hline$T_{1}(P P+$ Niger $)(1: 2) 90 \times 30 \mathrm{~cm}+30 \times 10 \mathrm{~cm}$ & 1070.74 & 699.8 & 3725.26 & 3398.82 & 4796.0 & 4098.62 & 22.35 & 17.07 \\
\hline$T_{2}(P P+$ Niger $)(1: 2) 90 \times 45 \mathrm{~cm}+30 \times 10 \mathrm{~cm}$ & 734.56 & 703.4 & 2968.43 & 3451.08 & 3703.0 & 4154.48 & 19.83 & 16.93 \\
\hline$T_{3}(P P+$ Niger $)(1: 3) 120 \times 30 \mathrm{~cm}+30 \times 10 \mathrm{~cm}$ & 1022.77 & 760.8 & 3213.24 & 3796.70 & 4236.0 & 4557.50 & 24.14 & 16.69 \\
\hline$T_{4}(P P+$ Niger $)(1: 3) 120 \times 45 \mathrm{~cm}+30 \times 10 \mathrm{~cm}$ & 718.66 & 762.5 & 2617.35 & 3828.62 & 3336.0 & 4591.12 & 21.54 & 16.60 \\
\hline$T_{5}(P P+$ Niger $)(1: 4) 150 \times 30 \mathrm{~cm}+30 \times 10 \mathrm{~cm}$ & 722.80 & 790.0 & $2871 . .20$ & 3882.65 & 3594.0 & 4672.65 & 20.11 & 16.90 \\
\hline$T_{6}(P P+$ Niger $)(1: 4) 150 \times 45 \mathrm{~cm}+30 \times 10 \mathrm{~cm}$ & 494.14 & 795.2 & 2382.85 & 3901.32 & 2877.0 & 4696.52 & 17.15 & 16.93 \\
\hline$T_{7}($ Solepigeonpea $) 90 \times 20 \mathrm{~cm}$ & 1650.00 & --- & 5165.00 & --- & 6815.0 & --- & 24.21 & --- \\
\hline$T_{8}$ ( Soleniger) $30 \times 10 \mathrm{~cm}$ & --- & 853.9 & --- & 4652.66 & --- & 5506.56 & --- & 15.50 \\
\hline $\mathbf{S E} \pm$ & 24.996 & 23.76 & 318.9 & 261.58 & 280.60 & 282.69 & --- & --- \\
\hline CD at $5 \%$ & 95.64 & 72.0 & 966.29 & 792.60 & 850.24 & 856.56 & --- & --- \\
\hline
\end{tabular}


Table.2 Pigeonpea equivalent yield (PEY) and Land equivalent proportion (LER), Area time equivalent ratio (ATER), Aggressivity as influenced by different treatments

\begin{tabular}{|c|c|c|c|c|}
\hline Treatment & $\begin{array}{c}\text { PEY } \\
\left(\mathrm{Kg} \mathrm{ha}^{-1}\right)\end{array}$ & LER & ATER & Aggressivity \\
\hline$T_{1}(P P+$ Niger $)(1: 2) 90 \times 30 \mathrm{~cm}+30 \times 10 \mathrm{~cm}$ & 1311.81 & 1.387 & 1.075 & 0.0070 \\
\hline$T_{2}(P P+$ Niger $)(1: 2) 90 \times 45 \mathrm{~cm}+30 \times 10 \mathrm{~cm}$ & 1077.77 & 1.219 & 0.873 & 0.0009 \\
\hline$T_{3}(P P+$ Niger $)(1: 3) 120 \times 30 \mathrm{~cm}+30 \times 10 \mathrm{~cm}$ & 1384.05 & 1.477 & 1.083 & 0.0129 \\
\hline$T_{4}(P P+$ Niger $)(1: 3) 120 \times 45 \mathrm{~cm}+30 \times 10 \mathrm{~cm}$ & 1127.64 & 1.292 & 0.900 & 0.0055 \\
\hline$T_{5}(P P+$ Niger $)(1: 4) 150 \times 30 \mathrm{~cm}+30 \times 10 \mathrm{~cm}$ & 1321.16 & 1.449 & 0.919 & 0.0103 \\
\hline$T_{6}(P P+$ Niger $)(1: 4) 150 \times 45 \mathrm{~cm}+30 \times 10 \mathrm{~cm}$ & 981.99 & 1.206 & 0.783 & 0.0033 \\
\hline$T_{7}($ Solepigeonpea $) 90 \times 20 \mathrm{~cm}$ & 1650.00 & 1.00 & 1.00 & ---- \\
\hline$T_{8}($ Soleniger) $30 \times 10 \mathrm{~cm}$ & 646.76 & 1.00 & 0.520 & ---- \\
\hline $\mathbf{S E} \pm$ & 188.00 & ---- & ----- & ---- \\
\hline CD at $5 \%$ & 564.00 & ----- & ----- & ----- \\
\hline
\end{tabular}

Minimum Support Price:- Pigeon pea - Rs.5050/- $\mathrm{q}^{-1}$ (Recommended / Fixed).

Minimum Support Price:- Niger $\quad-1$ Rs. 3825/- q $\quad$ (Recommended / Fixed).

Source of MSP: - cacp.dacnet.nic.in(Anonymous, 2017). 
Table.3 Gross monetary returns $(\mathrm{GMR})\left(\times 10^{3} /-\mathrm{ha}^{-1}\right)$, Cost of cultivation $\left(\times 10^{3} /-\mathrm{ha}^{-1}\right)$, net monetary returns $(\mathrm{NMR})\left(\times 10^{3} /-\mathrm{ha}^{-1}\right)$, and benefit: cost ratio (B: $\mathrm{C}$ ratio) of pigeonpea + niger intercropping system as influenced by different treatments

\begin{tabular}{|c|c|c|c|c|}
\hline Treatments & $\operatorname{GMR}\left(\times 10^{3} /-\mathrm{ha}^{-1}\right)$ & $\operatorname{COC}\left(\times 10^{3} /-\mathrm{ha}^{-1}\right)$ & $\operatorname{NMR}\left(\times{\underset{1}{1})}^{10} /-\right.$ ha $^{-}$ & B:C \\
\hline$T_{1}(P P+$ Niger $)(1: 2) 90 \times 30 \mathrm{~cm}+30 \times 10 \mathrm{~cm}$ & 69.890 & 23.325 & 46.565 & 2.95 \\
\hline$T_{2}(P P+$ Niger $)(1: 2) 90 \times 45 \mathrm{~cm}+30 \times 10 \mathrm{~cm}$ & 57.516 & 23.192 & 34.324 & 2.47 \\
\hline$T_{3}(P P+$ Niger $)(1: 3) 120 \times 30 \mathrm{~cm}+30 \times 10 \mathrm{~cm}$ & 73.253 & 23.270 & 49.983 & 3.14 \\
\hline$T_{4}(P P+$ Niger $)(1: 3) 120 \times 45 \mathrm{~cm}+30 \times 10 \mathrm{~cm}$ & 59.866 & 23.171 & 36.695 & 2.58 \\
\hline$T_{5}(P P+$ Niger $)(1: 4) 150 \times 30 \mathrm{~cm}+30 \times 10 \mathrm{~cm}$ & 69.842 & 23.225 & 46.617 & 3.00 \\
\hline$T_{6}(P P+$ Niger $)(1: 4) 150 \times 45 \mathrm{~cm}+30 \times 10 \mathrm{~cm}$ & 52.353 & 23.146 & 29.206 & 2.26 \\
\hline $\mathbf{T}_{7}($ Solepigeonpea $) 90 \times 20 \mathrm{~cm}$ & 87.198 & 23.284 & 63.914 & 3.74 \\
\hline$T_{8}$ ( Soleniger) 30x 10cm & 25.901 & 23.062 & 2.839 & 1.12 \\
\hline $\mathrm{SE} \pm$ & 3.252 & 1.22 & 3.19 & ---- \\
\hline CD at $5 \%$ & 9856.23 & NS & 9.6 & ---- \\
\hline
\end{tabular}


Area time equivalent ratio (ATER) differed significantly due to intercropping treatments comprising of planting geometry and row spacings. The significantly higher ATER was recorded when niger intercropped with pigeonpea in $120 \times 30 \mathrm{~cm}$ in 1: 3 row proportion followed by planting geometry 90 $\mathrm{x} 30 \mathrm{~cm}$ with $1: 2$ row proportion. Lowest ATER was recorded in sole niger $(30 \times 10 \mathrm{~cm})$ (0.520).Higher ATER values in the above mentioned intercropped treatments were due to higher combined seed yield per plant of both the crops per unit area and longer duration of the crop present on the land from planting to harvest

\section{Economics}

Costs of cultivation (Rs.23,325/- ha $^{-1}$ ) were recorded maximum when pigeonpea + niger crops were planted in narrow planting geometry i.e. $90 \times 30 \mathrm{~cm}$. It might be due to maximum seed requirement of pigeonpea + niger for sowing under respective treatment. The maximum gross monetary return (Rs.87198/- ha $^{-1}$ )and net monetary return (Rs.63914/- ha $^{-1}$ ) from sole pigeonpea were recorded in narrow planting geometry $(90 \mathrm{x}$ $20 \mathrm{~cm}$ ) which was significantly higher than rest of the different row proportions and planting geometries (pigeonpea + niger) which may be due to higher yield and absence of aggressivity of the intercrop. Among different pigeonpea and niger row proportions, 1: 3 recorded highest net returns (Rs.49983/- ha $^{-1}$ ) The results are in conformity with those reported by Lingaraju et al., (2008) from Bheemarayanagudi (Karnataka).

Maximum B: C ratio was recorded with narrow planting geometry of sole pigeonpea (3.74) i.e. $90 \times 20 \mathrm{~cm}$, lowest with sole niger (1.12) i.e. $30 \times 10 \mathrm{~cm}$ and intermediate (2.263.14) with different intercropping system, due to variance in gross monetary returns of different treatments.
From the results, it could be concluded that, farmer can obtained higher pigeonpea equivalent yield (PEY), GMR, NMR. B: C ratio under sole pigeonpea $\mathrm{T}$ with closer planting geometry of $90 \times 20 \mathrm{~cm}$ $\left(1650 \mathrm{~kg} \mathrm{ha}^{-1}\right)$. Among intercropping system $\mathrm{T}(120 \times 30 \mathrm{~cm})$ recorded highest PEY, LER, GMR, NMR. B: $\mathrm{C}$ ratio over all other treatments.

\section{References}

Gare, B.N., S.M. More, M.G. Jadhav and A.V. Burli. 2004. Effect of pigeonpea and sorghum intercrop on yield of soybean under rainfed condition in SubMontane Zone of Maharashtra. Journal of Maharashtra Agric. Univ, 29(2): 170-172.

Ghosh, P.K., M. Mohanty, K.K. Bandyopadhyay, D.K. Painuli and A.K. Misra. 2005. Growth, Competition, yield advantage and economics in soybean / pigeonpea intercropping system in semi-arid tropics of India I. Effect of sub soiling. Field Crops Research. 96: 80-89.

Jasna, V.K., R. Sukanya Som, R. Burman, RN. Padaria and JP. Sharma. 2014. Socio economic impact of climate resilient technologies. International Journal of Agriculture and Food Science Technology. 5(3): 185-190.

Lingaraju, B.S., S.B. Marer and S.S. Chandrashekar. 2008. Studies on intercropping of maize and pigeonpea under rainfed conditions in Northern Transitional Zone of Karnataka. Karnataka Journal of Agriculture Science, 21 (1): 1-3.

Patil, P.A. and P.K. Joshi. 2002. Effect of planting pattern in Pigeonpea and Soybean intercropping. J. Maharashtra Agric. Univ. 27 (3): 268-270.

Rao J.V., I.A. Khan, and Sujatha 2003. Critical review of research on 
intercropping systems in rainfed regions of India. National Agricultural Technological Project, Central Research Institute for Dryland Agriculture (CRIDA), Hyderabad, India.1-100.

Rathod, P.S., S.I. Halikatti, S.M. Hiremath and S.T. Kajjidoni. 2004. Influence of different intercrops and row proportions on yield and yield parameters of pigeonpea in Vertisols of Dharwad. Karnataka Journal of Agriculture Science. 17: 652-657.

Sonawane, D.A., S.S. IThe, T.M. Bahale and N.D. Dalavi. 2011. Evaluation of pigeonpea based intercropping systems under scarcity condition of Northern Maharashtra. JNKVV Research Journal. 45(1): 81-84.
Willey, R.W. 1979. Intercropping - its importance and research needs I. Competition and yield advantage. Field Crops Abstracts. 32: $1-10$ and $73-85$.

Willey, R.W., M.R. Rao and M. Natarajan. 1980. Traditional cropping systems with pigeonpea and their improvement. In: Proc. Inte. Workshop pigeonpea, December 15-19, 1980, ICRISAT, Patancheru. 11-25.

Yadav, P.S. and B.M. Maurya. 2012. Assessment of productivity and economics of various soybean + pigeonpea intercropping system under rainfed condition of Rewa region of Madhya Pradesh. JNKVV Research Journal. 46(3): 355-359.

\section{How to cite this article:}

Lavanya, Y., N.G. Kurhade and Pawar, G.R. 2018. Performance of Different Crop Geometry on Yield Advantage Assessment and Economics of Pigeonpea (Cajanus cajan) + Niger (Guizotia abyssinica Cass.) Intercropping System. Int.J.Curr.Microbiol.App.Sci. 7(11): 22942302. doi: https://doi.org/10.20546/ijcmas.2018.711.258 